\title{
Combined Domestic and Hospital Wastewaters Treatment by Natural Lagoon System in Tropical Area, Korhogo, Ivory Coast
}

\author{
Ouattara Koffi Nouho1,*, Kouamé Cyr-Kevin Yao ${ }^{1}$, Effebi Kokoh Rose², Ouattara Allassane ${ }^{1}$, Gourène Germain ${ }^{1}$ \\ ${ }^{1}$ Laboratory of Environment and Aquatic Biology, University of Nangui Abrogoua BP 801 Abidjan 02, Ivory Coast. \\ ${ }^{2}$ Laboratory of Geosciences, University of Nangui Abrogoua BP 801 Abidjan 02, Ivory Coast.
}

\section{A R T I C L E D E T A I L S}

Article history:

Received 15 October 2019

Accepted 24 October 2019

Available online 11 November 2019

\section{Keywords:}

Wastewater Pollution

Lagoon System

Fecal Bacteria

Water Reuse

Biosolids

\begin{abstract}
A B S T R A C T
Wastewaters discharged into surface waters highly impacted humans and living aquatic organisms particularly when the treatment applied to reduce chemical and biological pollution is not appropriated. Biological treatment systems are often applied for the treatment of domestic wastewaters. These systems are limited when applied to the treatment of hospital wastewaters. In this study, we evaluated the efficiency of natural lagoon system, applied to treat combined wastewaters from hospital and from residences of nursing students. Results show that the lagoon system remove $98 \%$ of COD, $87 \%$ of BOD, $95 \%$ of TSS and $92 \%$ of total nitrogen. Arsenic and copper are removed (40\%), but lead and cadmium concentrations increase in the effluent. Globally, the concentrations of nutrients and heavy metals, in the effluents, are inferiors to the limit values proposed by the Ivorian guidelines for water pollution. However, the reuse of effluents for irrigation of crops likely to be eaten uncooked is not recommended because of the high concentration of fecal bacteria $\left(1.00 \times 10^{5} \mathrm{CFU}\right.$ E. coli. $100 \mathrm{~mL}^{-1}$. The disinfection process must be implemented after biological treatment to ensure the elimination of pathogenic microorganisms present in the effluent and sludge, before their reuse in agriculture.
\end{abstract}

\section{Introduction}

Domestic and industrial activities produce large quantities of wastewater that containing various types of pollution (organic, pesticides, pathogenic microorganisms and Endocrine Disrupting Chemicals (EDC)). These wastewaters are sometimes discharged into surface water without any treatment. The pollutants present in these wastewaters can affect human's health and disturb ecological functioning of aquatic systems. In developing countries, the lack access to proper sanitation and global policies to manage wastewater (implementation of wastewater treatment plants) are responsible of raw wastewater discharge into surface water without treatment. Recently, in many African countries, efforts have been done to implement wastewaters treatment plants (WWTPs) for domestic and industrial wastewaters management. The stabilization pond systems (SPS) are the most WWTP technology used to treat domestic and also industrial wastewaters [1]. The SPS are composed by lagoons which applied physical treatment and biological treatment. The lagoon system requires constant monitoring to ensure their smooth operation otherwise the declining state of the system is observed [2]. Thus, effluent highly impacted humans and living aquatic organisms. In Côte d'Ivoire, since these two last decades, lagoon systems were implemented to treat industries and also domestic wastewaters. Recently, this technology was applied for the treatment of combined domestic and industrial wastewater in the north of the country. In general, the hospital wastewaters and domestic wastewaters are treated separately because of the limitation of classical biological system to eliminate micro-pollutants and other chemicals pollutants present in the hospitals wastewaters (Antibiotics, Iodinated contrast media, Estrogens). In spite of these limitations, the possibility to co-treat hospital and domestic wastewaters is now a serious option proposed [3]. Thus, a rigorous lagoon system or activated sludge can support the pollutants charges from these wastewaters.

In this study, the wastewaters from Regional Hospital Center (RHC) and from Medical Training Center (MTC) are treated by natural lagoon system composed by three lagoons. After treatment, the effluents are reused by farmer for irrigation of crops likely to be eaten uncooked without any control of water quality. In the scope of this study, we evaluate the quality

\section{*Corresponding Author:nouho_koffi@yahoo.fr(Ouattara Koffi Nouho)}

of the effluents, the efficiency of the natural lagoon system to treat the combined domestic from MTC and hospital wastewaters from RHC.

\section{Experimental Methods}

\subsection{Study Area}

Study was performed at Korhogo $\left(9^{\circ} 27^{\prime} \mathrm{N} 5^{\circ} 38^{\prime} \mathrm{W}\right)$, the fourth most populated Ivorian city. With more than 327,030 inhabitants [4], this city is located in the North of Ivory Coast (West Africa). The watershed of Korhogo is mostly composed by urban area and agriculture area including breeding. The whole domestic wastewaters of the city are drained into the only one municipal lagoon system excepted for the hospital (805 equivalent inhabitants) and the medical training center (equivalent 813 inhabitants). These are drained into the Medical Training Center WWTP. It is a natural lagoon system composed by three lagoons covering an area of $2136.9 \mathrm{~m}^{2}$. The WWTP of medical training center of Korhogo has a nominal capacity of $300 \mathrm{~m}^{3} \mathrm{day}^{-1}$ and is equipped by a primary treatment system in order to remove solid particles (screening system). The effluents of the WWTP are discharged into a small river located 500 meters from the WWTP via a buried collector. Along the river which receive effluent of WWTP, the farmers growth the salad, cucumber, carrot.

\subsection{Wastewater and Sediment Sampling and Processing}

Our experimental studies were performed in the natural lagoon system of the medical training center of Korhogo. This WWTP received the wastewaters from the Regional Hospital Center and also sewage waters from the medical students' dormitories. Samples were collected during two days, from 04.30 .2019 at $2 \mathrm{pm}$ to 05.01 .2019 at $5 \mathrm{pm}$. Three samples were collected at 13 stations for in situ physical and chemical parameters and at 4 stations for microbiological parameters and others chemicals specifics pollutants (Fig. 1).

In-situ analyses and the other physical and chemical parameters were performed following the specific requirement of standard rules analyses. These methods are well described by Tolulope et al. [5]. The Table 1 indicates the parameters which have been analyzed, the methods and references used for each parameter. Thus, in-situ parameters such as $\mathrm{pH}$, dissolved oxygen, conductivity, turbidity, TDS were measured in the WWTP of medical training center (Korhogo, Ivory Coast). For 
microbiological parameters (E. coli and intestinal enterococci) and chemicals parameters (BOD, COD, total nitrogen, total phosphorus, oil and greases, total suspended solids, heavy metals) samples were sent to Abidjan (more $600 \mathrm{~km}$ distance) for laboratory analysis. Samples brought in the laboratory were kept in the better preservation conditions $\left(4^{\circ} \mathrm{C}\right.$ temperature and acidic conditions for nutrients) during the transport. Microbiological parameters analyses were performed in the Laboratory of Environment and Aquatic Biology (LEBA, Nangui Abrogoua University in Ivory Coast) while the chemical parameters were performed in National Laboratory of Quality Testing, Metrology and Analyzes (LANEMA, Abidjan, Ivory Coast). The sediment samples were sent to the center of analyses and research of the national petroleum group (PETROCI, Abidjan Ivory Coast) for the heavy metal analyses.

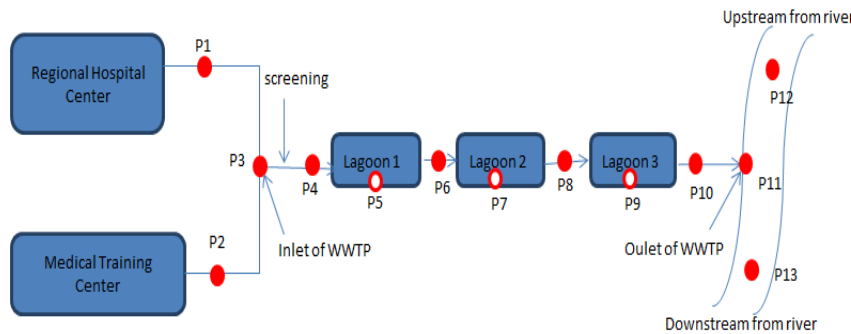

Fig. 1 Sampling stations in the WWTP of Medical Training Center of Korhogo (Ivory Coast). P1-P13 represents the sampling points. P3 and P11 indicate the inlet and the outlet of WWTP

\subsection{Physical and Chemical Parameters Analyses in Water and Sediment}

Ouattara et al. [6] reported that nutrients, temperature, $\mathrm{pH}$, conductivity, TSS and dissolved oxygen are some key parameters that play a vital role in the life of an aquatic system, particularly for the growth of microorganisms in the water body [7] and also in the biogeochemical cycles. At certain concentrations these pollutants are toxic to the aquatic environment. Their importance on the evaluation of water quality affected by sewage waters is well described by Erich et al. [8]. Another parameter which can help to determine the load of pollutant discharged into the natural aquatic system is the flow rate. This flow rate when multiplied by the concentration of a pollutant can permit to determine the load of this pollutant. In this study, the flow rates used to calculate the load of pollutants in the influent and the effluents was determined by measuring the volume of water passing by a point through an area during a period of time. In the scope of this study, six parameters were measured in-situ during the whole study period. Temperature, TDS, turbidity, conductivity dissolved oxygen and $\mathrm{pH}$ were measured using multi-parameter $\mathrm{HACH}$ HQ40D, according to standardized protocols of Rodier et al. [9].

\subsection{Nutrients and Heavy Metals Concentration}

Water samples were collected in the influent, the effluent of WWTP in order to determine the organic matter composition (COD and BOD), the total suspended solids, the nitrogen, the phosphorus, the oil and grease content in the water column. The concentration of these parameters in the water samples is key element to determine the water quality of the effluent but also to analyze the efficiency of the WWTP. The method and reference used to analyze these parameters are described in the Table 1.

The effluent and influent samples were also collected to determine the concentration of heavy metals in these samples. The sediments of the lagoon were also sampled to determine their content in heavy metals. These analyses were performed in order to evaluate the possibility to reuse the effluent of WWTP for agriculture and to determine efficiency of the lagoon treatment system to remove heavy metals.

\subsection{Microbiological Analyses}

\subsubsection{Traditional Culture based Methods for E. coli and Intestinal Enterococci}

Following the method described by Ouattara et al. [6], E. coli and IE were enumerated in the wastewater samples. Briefly, E. coli and Intestinal enterococci were determined by standard plate counts on TBX (E. coli) and Slanetz and Bartley agar (Bio-Rad Laboratories, Inc.). These chromogenic growth media were shown to be highly specific to their corresponding indicator bacteria $[10,11]$. These high levels of specificity were confirmed on samples from surface waters and sewage waters before analyses. Slanetz and Bartley supplemented with TTC $(0.2 \%)$ plates were incubated at $36^{\circ} \mathrm{C}$ for $24 \mathrm{~h}$ then at $44^{\circ} \mathrm{C}$ for $2 \mathrm{~h}$ before enumeration. TBX plates were incubated at $44^{\circ} \mathrm{C}$ for $24 \mathrm{~h}$. Plate counts were expressed as colony forming units (CFU) per $100 \mathrm{~mL}$ of sample. The protocols used to detect $E$. coli (TBX agar) and IE (Slanetz and Bartley agar) are well described by Vergine et al. [12] and Tiwari et al. [13] respectively.

https://doi.org/10.30799/jespr.183.19050404
Table 1 Presentation of analytical parameters methods [9]

\begin{tabular}{|c|c|}
\hline Analyses & Methods \\
\hline Organic matter (BOD and COD) & $\begin{array}{l}\text { Standardized method based on dissolved } \mathrm{O}_{2} \\
\text { consumption for BOD and standard test methods } \\
\text { for chemical oxygen demand (dichromate } \\
\text { oxidation). }\end{array}$ \\
\hline $\begin{array}{l}\text { Nitrogen (Kjeldahl, Total } \\
\text { nitrogen) }\end{array}$ & $\begin{array}{l}\text { UV method for nitrite and nitrate, Kjeldahl } \\
\text { digestion method. }\end{array}$ \\
\hline $\begin{array}{l}\text { Suspended solids } \\
\text { (TSS AND TVS) }\end{array}$ & $\begin{array}{l}\text { Gravimetric analysis is used to determine total } \\
\text { suspended solids (TSS) and total volatile solids } \\
\text { (TVS), also known as volatile suspended solids } \\
\text { (VSS) using a four place analytical balance }\end{array}$ \\
\hline $\begin{array}{l}\text { Phosphorus }\left(\mathrm{P}_{\mathrm{T}} \text { et } \mathrm{PO}_{4}{ }^{3-} \text { ) }\right. \\
\text { In situ parameters } \\
\text { (Temperature, TDS, } \mathrm{pH} \\
\text { Dissolved Oxygen, } \\
\text { conductivity) }\end{array}$ & $\begin{array}{l}\text { Spectrophotometric method } \\
\text { Multi-parameter HACH HQ40D method using } \\
\text { specific probes for each parameter }\end{array}$ \\
\hline $\begin{array}{l}\text { Fecal indicator bacteria (E. coli, } \\
\text { Intestinal Enterococci }\end{array}$ & $\begin{array}{l}\text { Plate count method: (Filtration and surface } \\
\text { spreading methods) }\end{array}$ \\
\hline $\begin{array}{l}\text { Heavy metals (Pb, Cadmium, } \\
\text { Arsenic, Lead, Chromium) }\end{array}$ & $\begin{array}{l}\text { Atomic absorption spectrometry method } \\
\text { and microscopy method using a scanning } \\
\text { electron microscope }\end{array}$ \\
\hline Oil and Greases & Hexane extractable gravimetric method \\
\hline
\end{tabular}

\section{Results and Discussion}

\subsection{Physical and Chemical Parameters}

\subsubsection{In-Situ Parameters}

Table 2 presents the concentrations of chemical parameters and the values of the physical parameters measured, in-situ in the influent and the effluents of the WWTP lagoon treatment system. Globally, the temperatures values, in all the sampling stations varied between $26^{\circ} \mathrm{C}$ and $32{ }^{\circ} \mathrm{C}$ in the whole WWTP drainage network system. In the effluent, the temperature ranged between $29-32.4^{\circ} \mathrm{C}$. These values are lower than the limit value recommended by Ivorian guideline (temperature must be inferior to $40^{\circ} \mathrm{C}$ ). The $\mathrm{pH}$ values in the effluent are globally higher than the reference value of the Ivorian guideline limit of 9.5 .

Table 2 Concentrations and values of chemical parameters at sampling stations

\begin{tabular}{llllllll}
\hline Source & $\begin{array}{l}\text { Code Temp. } \\
\left({ }^{\circ} \mathrm{C}\right)\end{array}$ & $\mathrm{pH}$ & DO $(\%)$ & $\begin{array}{l}\text { Cond. } \\
(\mu \mathrm{s} / \mathrm{cm})\end{array}$ & $\begin{array}{l}\text { Turb. } \\
(\mathrm{NTU})\end{array}$ & $\begin{array}{l}\text { TDS } \\
(\mathrm{ppm})\end{array}$ \\
\hline RHC & P1 & $29.8-$ & $10.03-$ & $58.40-$ & $244-$ & $6.53-$ & $122-$ \\
& & 31.3 & 11.12 & 77.3 & 432 & 12.7 & 216 \\
MTC & P2 & $29-$ & $10.8-$ & $46.6-$ & $286-$ & $54.2-$ & $143-$ \\
& & 31.3 & 11.27 & 56.70 & 588 & 154 & 295 \\
RHC and & P3 & $26.9-$ & $8.62-$ & $37.8-$ & $385-$ & $62.1-$ & $215-$ \\
MTC & & 30.1 & 11.1 & 40.8 & 640 & $89.4-$ & 320 \\
Inlet of & P4 & $28.4-$ & $7.99-$ & $22.6-$ & $281-$ & $24.2-$ & $141-$ \\
Lagoon 1 & & 31.4 & 8.96 & 22.6 & 389 & 28.4 & 195 \\
Lagoon 1 & P5 & $28.8-$ & $8.5-$ & $27.5-$ & $517-$ & $53.4-$ & $259-$ \\
& & 32 & 8.75 & 30.7 & 613 & 81.1 & 307 \\
Outlet of & P6 & $28.8-$ & $7.90-$ & $26-$ & $489-$ & $20.4-$ & $245-$ \\
Lagoon 1 & & 31.4 & 8.21 & 28 & 494 & 21.9 & 265 \\
Lagoon 2 & P7 & $28.9-$ & $8.10-$ & $43.0-$ & $539-$ & $46.3-$ & $250-$ \\
& & 29.6 & 8.5 & 44.1 & 560 & 47.8 & 270 \\
Outlet of & P8 & $28.8-$ & $7.21-$ & $50.1-$ & $491-$ & $40.1-$ & $246-$ \\
Lagoon 2 & & 30.2 & 7.68 & 52.3 & 509 & 42.6 & 256 \\
Lagoon 3 & P9 & $29.2-$ & $8.02-$ & $65.1-$ & $465-$ & $50.8-$ & $226-$ \\
& & 30.7 & 8.5 & 66.0 & 487 & 52.6 & 228 \\
Outlet of & P10 & $27.7-$ & $8.99-$ & $50.4-$ & $450-$ & $44-$ & $225-$ \\
Lagoon 3 & & 33.4 & 12.72 & 76.7 & 491 & 140 & 246 \\
Effluent of P11 & $29-$ & $11.13-$ & $16.86-$ & $469-$ & $40.1-$ & $238-$ \\
the WWTP & 32.4 & 12.56 & 64.7 & 514 & 90.7 & 257 \\
Downstr & P12 & $28-31.9$ & $10.53-$ & $50.3-$ & $165-$ & $23.5-$ & $82.5-$ \\
eam & & & 10.72 & 68.7 & 189 & 28.6 & 94.6 \\
Up & P13 & $28-$ & $10.93-$ & $54.7-$ & $189-$ & $27.6-$ & $94.9-$ \\
stream & & 32 & 11.26 & 67.6 & 190 & 33.8 & 95.3 \\
\hline
\end{tabular}

*Three samples were collected and analyzed separately to determine diurnal variation. Data recorded represent the minimum and the maximum values. The influent and the effluents are highlighted in bold. MTC (Medical Training Center) and RHC (Regional Hospital Center)

The conductivity values in the effluent ranged between $469-514$ $\mu \mathrm{s} / \mathrm{cm}$. The TDS of the effluent value ranged between $238-257 \mathrm{ppm}$. The reference values of these two parameters are not specified in the Ivorian guidelines for water quality. These values were compared to the reference 
value proposed by Kahila et al. [14] concerning the reuse effluent for agriculture which are $0-3 \mathrm{dS} / \mathrm{m}(0-3000 \mu \mathrm{s} / \mathrm{cm})$ and $0-2,000 \mathrm{mg} / \mathrm{L}$ (or $\mathrm{ppm}$ ) for conductivity and TDS respectively. Thus, the conductivity and the TDS values in the effluent are lower than the reference value indicating that the reuses of these effluents for agriculture purpose do not present a specific health risk concerning these in-situ parameters.

The dissolved oxygen concentrations are relatively low in the three lagoons and also in the WWTP effluent. The average value of dissolved oxygen in the effluent is inferior to $60 \%$, the reference value of dissolved oxygen in the effluent. The low dissolved oxygen values in the effluent could have a negative effect on the activities of aerobically microbial in the recycling of organic matter in the water.

\subsubsection{Chemical Parameters (Nutrients) in Wastewaters}

The nutrients levels in the effluents are key parameters in the evaluation of water quality because their strongly impacted the aquatic systems. The concentration of nutrients and the limit values of these nutrients that can be discharged into aquatic system are indicated in the Table 3. The average values of COD and $\mathrm{BOD}_{5}$ in the influent were 463 $\mathrm{mgL}^{-1}$ and $300 \mathrm{mgL}^{-1}$ respectively. The BOD ${ }_{5}$ represents the part of COD that can be oxidized by micro-organisms justifying the fact that COD was higher than $\mathrm{BOD}_{5}$. The proportion of the biodegradability part of this organic matter represents more than $50 \%$ of the COD. The application of biological treatment to these influents could be accepted even if the nonbiological oxidative part of organic materials in the water is not negligible. The BOD is composed by two fractions: the dissolved BOD and the particulate BOD. The dissolved $\mathrm{BOD}_{5}$ represents more than $73 \%$ of the total BOD in the influent and more than $94 \%$ in the effluent. The total suspended solids (TSS) is composed by two fractions: The volatile suspended solids (VSS) and dry solids. The VSS represents $89 \%$ of the TSS in the influent and $75 \%$ in the effluent. TSS is highly composed by biological material then could be easily degraded in the natural surface waters. The biological treatment removed $98 \%$ of COD, 87\% of BOD, 95\% of total suspended solids and $92 \%$ of total nitrogen. The concentration of total phosphorus, oil and grease and phosphate were in the effluent than in the influent. Thus, an increase of $54 \%$ for PT, $50 \%$ for oil and grease and $39 \%$ for phosphate were recorded in the water samples.

Table 3 Concentrations of chemical parameters in the WWTP influent and effluents

\begin{tabular}{lllll}
\hline Parameters & Units & $\begin{array}{l}\text { Conc. } \\
\text { (Influent of } \\
\text { WWTP) }\end{array}$ & $\begin{array}{l}\text { Conc. } \\
\text { (Effluent of } \\
\text { WWTP) }\end{array}$ & $\begin{array}{l}\text { *Limit } \\
\text { values }\end{array}$ \\
\hline COD & $\mathrm{mg} / \mathrm{L} \mathrm{O}_{2}$ & 463 & 49 & $300-500$ \\
BOD5 & $\mathrm{mg} / \mathrm{L} \mathrm{O}_{2}$ & 300 & 37 & $100-150$ \\
Filtrated BOD5 & $\mathrm{mg} / \mathrm{L} \mathrm{O}_{2}$ & 220 & 30 & \\
TSS & $\mathrm{mg} / \mathrm{L}$ & 181 & 8,50 & $50-150$ \\
VSS & $\mathrm{mg} / \mathrm{L}$ & 161 & 6,4 & - \\
Total phosphorus (P & $\mathrm{mg} / \mathrm{L} \mathrm{P}$ & 4.78 & 7,36 & 15 \\
Total Kjeldahl Nitrogen & $\mathrm{mg} / \mathrm{L} \mathrm{N}$ & 111.80 & 8.13 & - \\
(TKN) & & & & \\
Oil and grease & $\mathrm{mg} / \mathrm{L}$ & 2 & 4 & $10-30$ \\
Total Nitrogen & $\mathrm{mg} / \mathrm{L} \mathrm{N}$ & 112.13 & 9.12 & 50 \\
Phosphate & $\mathrm{mg} / \mathrm{L} \mathrm{PO}_{4}$ & 8.747 & 12.13 & - \\
\hline
\end{tabular}

*Ivorian guidelines for water pollution (ARRETE $N^{\circ} 01164$ du 04 November 2008 Portant Réglementation des Rejets et Emissions des Installations Classées pour la Protection de l'Environnement. For COD, BOD, TSS and oil and grease, the limit depend on the flux of these parameters in the influents

Globally, the concentrations of BOD, COD, oil and grease, TSS, nitrogen and phosphorus in the effluent are lower than the guidelines values recommended by Ivorian national policies for the effluents (Table 3).

\subsubsection{Heavy Metals Concentration in the Water Column}

Table 4 presents the concentration of cadmium, lead, arsenic and copper in the influent and the effluent of wastewater treatment plants. The values are expressed as the quantity of pollutant per volume of wastewater analyzed. For lead and cadmium, the concentrations are lower in the influent compare to their concentrations in the effluent. For arsenic and copper, more than $40 \%$ of these heavy metals were removed by the lagoon treatment system. The concentrations of these heavy metals are lower than the acceptable level required for their discharge into natural surface waters following the Ivorian guidelines for water. This law does not indicate the reference values for the use of these effluents for agriculture. Based on the international reference values proposed by WHO [15] and Vélez et al. [16] for water reuse, the concentration of heavy metals observed in the effluent are lower than the limit values recommended. With these concentrations, effluent used for irrigation of crops (tomatoes, cucumbers, etc.) do not present a sanitary risk.

https://doi.org/10.30799/jespr.183.19050404
Table 4 Concentrations of heavy metals in the water column of the WWTP influent and effluents

\begin{tabular}{llllll}
\hline Parameters & Units & $\begin{array}{l}\text { Conc. } \\
\text { (Influent of } \\
\text { WWTP) }\end{array}$ & $\begin{array}{l}\text { Conc. } \\
\text { (Effluent of } \\
\text { WWTP) }\end{array}$ & $\begin{array}{l}\text { *Ivorian } \\
\text { Limit } \\
\text { values of } \\
\text { effluent }\end{array}$ & $\begin{array}{l}\text { **International } \\
\text { limit and range }\end{array}$ \\
\hline Cadmium & $\mu \mathrm{g} / \mathrm{L}$ & 1.02 & 1.35 & - & 200 \\
Lead & $\mu \mathrm{g} / \mathrm{L}$ & 8.09 & 13.4 & 500 & 500 \\
Arsenic & $\mu \mathrm{g} / \mathrm{L}$ & 1.40 & 0.81 & - & 100 \\
Copper & $\mu \mathrm{g} / \mathrm{L}$ & 16.5 & 9.06 & 500 & 200 \\
\hline
\end{tabular}

*Ivorian guidelines for water pollution (ARRETE $N^{\circ} 01164$ du 04 November 2008 Portant Réglementation des Rejets et Emissions des Installations Classées pour la Protection de l'Environnement.

** World Health Organisation (2006b) and US Environmental Protection Agency (2012)

\subsection{Microbiological Parameters in the Water Column}

Five sampling stations were identified to determine the concentration of fecal indicator bacteria $E$ coli and intestinal enterococci in order to evaluate the microbiological quality of effluent and also analyses the efficiency of WWTP concerning the removal of FIB. The concentration releases by WWTP were also compared to the level observed in the river in order to appreciate their potential contribution in the pollution of the river. Abundances of FIB released are $1 \times 10^{5}$ and $5 \times 10^{4} \mathrm{CFU} 100 \mathrm{~mL}^{-1}$ for E. coli and intestinal enterococci respectively (Table 5). These values are in the same order of magnitude with the concentration in the effluents of classical biological WWTP. When we compared these concentrations to those observed in the river (upstream and downstream from the river) there is no significant difference. However, the concentrations of FIB in the effluent are higher than those recommended by the guidelines for the microbiological quality of treated wastewater used in agriculture [17]. The reuse conditions for Irrigation of crops likely to be eaten uncooked indicate that the concentration of fecal coliform should be less or equal to $1000 \mathrm{CFU} 100 \mathrm{~mL}^{-1}$.

The efficiency of this WWTP concerning the removal of FIB is around 2 $\log$ units for both indicators bacteria. This efficiency is also reported by Sheludchenko et al. [18] highlighting the fact that biological treatment systems are able to remove $90 \%$ of fecal bacteria or more in the wastewaters.

Table 5 Concentrations of fecal indicator bacteria in the water column of the WWTP influent and effluents

\begin{tabular}{lll}
\hline Stations & $\begin{array}{l}\text { Concentration E. coli } \\
\left(\mathrm{CFU} 100 \mathrm{~mL}^{-1}\right)\end{array}$ & $\begin{array}{l}\text { Concentration IE } \\
\left(\mathrm{CFU} 100 \mathrm{~mL}^{-1}\right)\end{array}$ \\
\hline Influent of WWTP & $1.01 \times 10^{7}$ & $4.20 \times 10^{6}$ \\
Effluent of WWTP & $1.00 \times 10^{5}$ & $5.00 \times 10^{4}$ \\
Upstream from the river & $7.50 \times 10^{4}$ & $2.50 \times 10^{4}$ \\
Downtream from the river & $1.50 \times 10^{4}$ & $1.00 \times 10^{4}$ \\
\hline
\end{tabular}

\subsection{Chemical Parameters in the Sediments of the Lagoon}

Analyses were performed in the sediments of the lagoon systems. These sediments are often used as fertilizer in urban agriculture. Presence and concentration of some chemical agents $(\mathrm{Pb}, \mathrm{Cr}, \mathrm{As}, \mathrm{Cu}, \mathrm{Cd}$ and $\mathrm{Hg}$ ) represent sanitary risks for populations. Table 6 presents the concentration of zinc, copper, chromium, lead, nickel, cadmium, selenium, mercury and arsenic present in the sediment of the lagoons. Excepted $\mathrm{Cd}$, Se and $\mathrm{Hg}$, the whole heavy metals were identified as molecules composed by oxygen and the atom itself.

Table 6 Concentrations of heavy metals in the sediment (sludge) of the WWTP lagoons

\begin{tabular}{llll}
\hline Symbols & Element & Concentration $(\mathrm{ppm})$ & Concentration $(\mathrm{g} / 1 \mathrm{Kg})$ \\
\hline $\mathrm{ZnO}$ & Zinc & 2202 & 2.2 \\
$\mathrm{CuO}$ & Copper & 478.1 & 0.45 \\
$\mathrm{Cr}_{2} \mathrm{O}_{3}$ & Chromium & 552.3 & 0.55 \\
$\mathrm{PbO}$ & Lead & 244.3 & 0.24 \\
$\mathrm{NiO}$ & Nickel & 222.1 & 0.22 \\
$\mathrm{Cd}$ & Cadmium & 26.0 & 0.026 \\
$\mathrm{Se}$ & Sélénium & 1.6 & 0.0016 \\
$\mathrm{Hg}$ & Mercury & $<1.0$ & 0.001 \\
$\mathrm{As}_{2} \mathrm{O}_{3}$ & Arsenic & $<0.7$ & 0.0007 \\
\hline
\end{tabular}

*Data corresponded to the sediment of the lagoon analyzed with electronic microscopy coupled to Energy Dispersive X-ray Spectrometry (EDS) (FEG Supra 40 VP-Zeiss)

The parameters like zinc, chromium, copper and lead are the most important chemical agents present in the sediment. There was a factor 10 100 between their values and those of cadmium, selenium, mercury and arsenic. the concentration of heavy metals was also expressed as mass of 
chemical agent per mass of total sediment in order to evaluate the possibility of sediment reuse as fertilizer in agriculture without any sanitary problems. Following the recommendation of biosolids in agriculture based on the concentration of heavy metals, the concentration of $\mathrm{As}, \mathrm{Cd}, \mathrm{Cr}, \mathrm{Hg}, \mathrm{Ni}, \mathrm{Pb}$, Se observed in this study are lower than those proposed in USA [19], in Europe [20].

The concentrations of physic and chemical parameters of the effluent discharged by the biological WWTP are lower than the guidelines values proposed by the Ivorian environmental policies [21]. Globally, these wastewaters are very weakly charged. The wastewaters from students' dormitories at MTC are highly diluted because of water leaks in the collector's network.

The compliance with discharge standards of release does not necessarily imply the reuse of these waters for irrigation for example. As demonstrated by our study, these waters contain high level of fecal bacteria $\left(10^{5} \mathrm{CFU} 100 \mathrm{~mL}^{-1}\right.$ and $10^{4} \mathrm{CFU} 100 \mathrm{~mL}^{-1}$ for E. coli and IE respectively). At these concentrations we cannot exclude the presence of pathogenic microorganisms (Vibrio, Salmonella, Ascaris and Trichuris etc...) in these waters. The presence of heavy metals and their concentrations also highlighted the worse quality of these waters for agriculture. The reuse of treated water for irrigation may be conditioned by many criteria to preserve the health of populations [22]

The presence and the high concentration of heavy metals and other complex chemical compound in effluent of WWTP indicate a potential connection to industrials or hospitals wastewaters. These wastewaters are more complex to be treated because of the presence of multiresistance microbiological pathogens, the hazardous chemicals, the pharmaceuticals and the radioactive isotopes. The management of these sewage waters was to limit the discharge of Hazardous liquid to domestic sewers. The connection of health-care establishment's wastewaters to "municipal or domestic" sewage treatment plant is possible and required many conditions such as the good efficiency of biological treatment system and quantities of toxic chemicals/pharmaceuticals. Then a "secondary bacteriological treatment of sewage, properly applied, complemented by anaerobic digestion of sludge, can be considered as sufficient". In our case, waters were discharged into the river after lagoon treatment system and there was no anaerobic digestion of sludge.

In this study, the efficiencies of biological treatment are: $88-89 \%$ for organic matter content (COD and BOD) and $2 \log -3 \log$ unit removal for IE and E. coli respectively (90-99\%). These efficiencies were also observed by Amouei et al. [23] who investigate efficiencies of wastewaters from four hospitals in IRAN during 2010 to 2011. Rezaee et al. [22] also indicate similar efficiency values for organic matter removal with a coupled aerobic and anaerobic biological treatment system applied to wastewater from Shevom Shaban hospital (Iran). However, the fecal bacteria removal in our case study were higher than the $1 \log$ unit and $2 \log$ unit observed by these authors. The long residence time of lagoon system contribute to increase their fecal bacteria removal efficiency when compared to other biological treatment systems.

The assumption that hospital and urban wastewaters are similar and can be co treated by the same treatment system pose a serious problem because of the presence of organic micro-pollutants (active pharmaceutical compounds) sometimes only present in hospital wastewaters and difficult to remove by classical treatment. Novel technologies such as the membrane biofilm bioreactor (MBBR) or SpongeMBR combined with ozonation process are more suitable for the elimination of these compounds (endocrine disrupting compounds) $[24,25]$.

Based on our results and finding, the reuse of effluent in agriculture do not pose a health problem concerning the heavy metals concentration. However, the concentrations of fecal bacteria in the effluent, limit the reuse of the effluent in agriculture particularly for crops likely to be eaten uncooked [17]. Additionally, Ait-Mouheb et al. [26] reported that the fecal bacteria present in these wastewaters also develop multi-resistance to antibiotics. The practice of effluent reuse in agriculture is highly disseminated around the world [27]. Recently in Africa, studies were performed to evaluate the opportunities to reuse effluent for agriculture and the results indicate many limitations such us the controls of water quality before their uses $[28,29]$. The main recommendation was safety conditions that must be guaranteed before reuse in agriculture particularly for urban crops likely to be eaten uncooked. The monitoring studies must integrate the new micro pollutants often present in the effluent of wastewaters from some industries and hospitals. Then, the reevaluation of the treatment technologies must also be undertaken and the application of novel technologies able to remove efficiently the micro pollutants must also be implemented.

During the biological treatment, there was an important sludge production. These are removed periodically in order to improve the lagoon treatment system. The sludge removed from lagoon system are https://doi.org/10.30799/jespr.183.19050404 often dried and used as fertilizer without specific monitoring studies focused on the presence and the concentration of micropollutants (heavy metals and pharmaceuticals) and pathogenic microorganisms (bacteria, virus and protozoa). The presence of heavy metals, pharmaceuticals and pathogenic microorganism in the sludge from WWTP is reported in many studies [30-32].

In our study, the results indicated the presence of low quantities of heavy metals $(\mathrm{Pb}, \mathrm{Cr}, \mathrm{As}, \mathrm{Cu}, \mathrm{Cd}$ and $\mathrm{Hg}$ ) in the sludge from lagoon system. The comparison performed between these values and those are reported by EEA [33], indicated that the concentrations recorded were lower than these references values.

The reuse of biosolids must also respect the microbiological quality of sludge before application in agriculture. Today, many technics are proposed to remove efficiently the pathogenic microorganisms present in the sludge [34]. Amount these processes the main technology often used is air drying process in Sub Saharan African countries because of the temperature. The removal of fecal bacteria using the air-drying process seems to be efficient with around 2 and $3 \log$ removal of FIB.

\section{Conclusion}

Natural lagoon system involved biological process that break down organic matter and recycle nutrients in order to guarantee the quality of the effluents. This technology is applied worldwide for domestic and specific industrial wastewaters (food industries). The application of this technology to treat separately hospital wastewaters and combined hospital and domestic wastewater is now suggested by sometimes criticized because of the presence of pharmaceuticals, and other heavy metals in the influent. The present study examines the efficiency of a natural lagoon system to treat combined sewage water from domestic and hospital origins. The results indicate that natural lagoon system proposed is able to remove organic pollutants, nutrients and heavy metals. The quality of effluent was in concordance with the limit values recommended by the Ivorian guideline for water quality. Additionally, the concentration of the different parameters examines indicate that the reuse of water does not present a specific health risk excepted for microbial parameters. We also found that the sediment could be reuse for agriculture even if the airdrying process has some limitation about the removal all pathogenic microorganisms.

This study completes our knowledge on the ability of natural lagoon system to treat efficiently the major chemical pollutant and offer the possibility to reuse the effluent and the bio solids as fertilizers in agriculture. The major limitation of this study is the determination of pharmaceuticals and ECC which are now considered as serious pollutants, detectable with novel technology of analyses. It should be therefore important to complete the monitoring process of effluents and sludge by including the micro-pollutants before their reuse in agriculture. The safety of population depends on it.

\section{Acknowledgement}

This study has been performed in the scope of the rehabilitation of the WWTP of the Medical center of Korhogo. Thanks to the authorities of the Regional Hospital Center and Medical training Center of Korhogo for the access to the WWTP and its drainage network.

\section{References}

[1] H. Wang, T. Wang, B. Zhang, F. Li, B. Toure, et al., Water and wastewater treatment in Africa - current practices and challenges, Clean Soil, Air, Water 42(8) (2014) 1029-1035.

[2] V. Mema, Impact of poorly maintained wastewater sewage treatment plants lessons from South Africa: wastewater management, Resource 12(3) (2010) 60-65.

[3] B. Pauwels, W. Verstraete, The treatment of hospital wastewater: an appraisal J. Water Health 4(4) (2006) 405-416.

[4] GCPH, Principles and recommendations for population and housing censuses, General Census of Population and Housing, Secretariat Permanent Technique of the GCPH Technical Committee, USA, 2014.

[5] T.E. Aniyikaiye, T. Oluseyi, J.N. Edokpayi, J.O. Odiyo, Physico-chemical analysis of wastewater discharge from selected paint industries in Lagos, Nigeria, Int. J. Environ. Res. Public Health 16(7) (2019) 1235:1-17.

[6] N.K. Ouattara, C.K.Y. Kouamé, B. Kamagaté, L.G. Droh, A. Ouattara, G. Gourène, Impact of faecal bacteria contamination on drinking water supply in Aghien Lagoon, Abidjan, Ivory Coast, Afr. J. Microbiol. Res. 12(42) (2018) 965-972.

[7] U.M. Qureshimatva, R.R. Maurya, S.B. Gamit, R.D. Patel, H.A. Solanki, Determination of physico-chemical parameters and water quality index (Wqi) of Chandlodia Lake, Ahmedabad, Gujarat, India, J. Environ. Anal. Toxicol. 5 (288) (2015) 1-6. 
[8] A. Errich, S. El Hajjaji, L. Mandi, M. Fekhaoui, B. Rezzouki, et al., Impact of waste water on the physico-chemical quality of water sources in bed of Oued Essaquia elhamra in South of Morocco, Int. J. Appl. Innov. Eng. Manage 5(9) (2016) 249 261.

[9] J. Rodier, B. Legube, N. Merlet, The analysis of the water, 9 th Edn., Dunod, Paris, 2009.

[10] ISO 7899-2:2000, Water quality - Detection and enumeration of intestinal enterococci - Part 2: Membrane filtration method, Geneva, 2000.

[11] ISO 16649-2:2001, Microbiology of food and animal feeding stuffs - Horizontal method for the enumeration of beta-glucuronidase-positive Escherichia coli Part 2: Colony-count technique at 44 degrees $\mathrm{C}$ using 5-bromo-4-chloro-3indolyl beta-D-glucuronide, Geneva, 2001.

[12] P. Vergine, C. Salerno, E. Barca, G. Berardi, A. Pollice, Identification of the faecal indicator Escherichia coli in wastewater through the $\beta$-D-glucuronidase activity: comparison between two enumeration methods, membrane filtration with TBX agar, and Colilert $($-18, J. Water Health 15(2) (2016) 209-217.

[13] A. Tiwari, A.M. Hokajärvi, J.W. Santo Domingo, A. Kauppinen, M. Elk, et al., Categorical performance characteristics of method ISO 7899-2 and indicator value of intestinal enterococci for bathing water quality monitoring, J. Water Health 16(5) (2018) 711-723.

[14] J. Kihila, K.M. Mtei, K.N. Njau, A review of the challenges and opportunities for water reuse in irrigation with a focus on its prospects in Tanzania, Int. J. Environ. Eng. 7(2) (2015) 111-130.

[15] WHO, Guidelines for the safe use of wastewater, excreta and greywater, Wastewater use in agriculture, World Health Organization, Geneva, 2006

[16] O.R. Vélez, G.E. Fasciolo, A.V. Bertranou, Domestic wastewater treatment in waste stabilization ponds for irrigation in Mendoza, Argentina: policies and challenges, Water Sci. Technol. 45(1) (2002) 127-132.

[17] U.J. Blumenthal, D.D. Mara, A. Peasey, G. Ruiz-Palacios, R. Stott, Guidelines for the microbiological quality of treated wastewater used in agriculture: recommendations for revising WHO guidelines, Bull. World Health Organ. 78(9) (2000) 1104-1116.

[18] M. Sheludchenko, A. Padovan, M. Katouli, H. Stratton, Supplementary Materials: Removal of faecal indicators, pathogenic bacteria, adenovirus, Cryptosporidium and Giardia (oo)cysts in waste stabilization ponds in Northern and Eastern Australia, Int. J. Environ. Res. Public Health. 13(1) (2016) 96:1-18.

[19] US EPA, Draft guidance on the use of models and other analyses in attainment demonstrations for the 8-hour ozone NAAQS, EPA-454/R-99-004, EPA, USA, 1999.

[20] H. Hudcová, J. Vymazal, M. Rozkošný, Present restrictions of sewage sludge application in agriculture within the European Union, Soil Water Res. 14(2) (2019) 104-120.
[21] CIAPOL, Regulation of discharges and emissions of classified installations for environmental protection, Order No. 01164, Centre Ivoirien Antipolution, Mineef, Ivory Coast, 2008

[22] A. Rezaee, M. Ansari, A. Khavanin, A. Sabzali, M.M. Aryan, Hospital wastewater treatment using an integrated anaerobic aerobic fixed film bioreactor, Am. J. Environ. Sci. 1(4) (2005) 259-263.

[23] A. Amouei, H.A. Asgharnia, A.A. Mohammadi, H. Fallah, R. Dehghani, M.B. Miranzadeh, Investigation of hospital wastewater treatment plant efficiency in north of Iran during 2010-2011, Int. J. Phys. Sci. 7(31) (2012) 5213-5217.

[24] L. Kovalova, H. Siegrist, H. Singer, A. Wittmer, C.S. McArdell, Hospital wastewater treatment by membrane bioreactor: performance and efficiency for organic micropollutant elimination, Environ. Sci. Technol. 46(3) (2012) 1536-1545.

[25] T.K. Quyen, V.X. Thanh, B.S. Shing, C.P. Dan Nguyen, N.D. Thanh, et al., Hospital wastewater treatment by sponge membrane bioreactor coupled with ozonation process, Chemosphere 230 (2019) 377-383.

[26] N. Ait-Mouheb, A. Bahri, B.B. Thayer, B. Benyahia, G. Bourrié, et al., The reuse of reclaimed water for irrigation around the Mediterranean Rim: a step towards a more virtuous cycle?, Reg. Environ. Change 18(3) (2018) 693-705.

[27] F. Jaramillo, M.I. Restrepo, Review wastewater reuse in agriculture: A review about its limitations and benefits, Sustainability 9(10) (2017) 1734.

[28] J.R. Adewumi, A.A. Ilemobade, J.E. Van Zyl, Treated wastewater reuse in South Africa: overview, potential and challenges, Resour. Conserv. Recycl. 55(2) (2010) 221-231.

[29] J. Kihila, K.N. Njau, K. Mtei, A review of the challenges and opportunities for water reuse in irrigation with a focus on its prospects in Tanzania, Int. J. Environ. Eng. 7(2) (2015) 110-130.

[30] S.R. Smith, Sludge (biosolids) and their significance for agricultural recycling, Phil. Trans. R. Soc. A 367 (2009) 4005-4041.

[31] I.K. Kalavrouziotis, P. Koukoulakis, Wastewater and sludge reuse management in agriculture, J. Environ. Qual. 20 (2016) 1-13.

[32] C.A. Villamar, I. Vera-Puerto, D. Rivera, F. De la Hoz, Reuse and recycling of livestock and municipal wastewater in Chilean agriculture: A preliminary assessment, Water 10 (2018) 817-832.

[33] EEA, The protection of the environment, and in particular of the soil, when sewage sludge is used in agriculture, Council Directive 86/278/EEC, European Environment Agency, Ireland, 1986.

[34] A. Al Gheethi, A.N. Efaq, J.D. Bala, I. Norli, M.O.A. Monem, M.O. Ab. Kadir, Removal of pathogenic bacteria from sewage treated effluent and biosolids for agricultural purposes, Appl. Water Sci. 8(2) (2018) 74-97. 